\title{
MEDIA RELATIONS ACTIVITIES AS A PUBLIC RELATION STRATEGY IMPLEMENTATION OF PT. TOYOTA ASTRA MOTOR
}

\author{
Galih Akbar Prabowo \\ Institut Agama Islam Negeri Ponorogo \\ Jl. Puspita Jaya, Jenangan, Ponorogo \\ email: galihakbar77@gmail.com
}

\begin{abstract}
Public relations have an important role in a company. Not only in the effort to ensure good relations with the internal stakeholders, but also with its external stakeholders. In relation to external stakeholders, the media is one of the parties that have important roles in the formation of the company image. PT. Toyota Astra Motor as an international scale automotive company is an example of a company that owns a large commitment to building a good relation with media. Media relations activities conducted by the company have been proving that PT. Toyota Astra Motor not only placed the press as an instrument to build a positive image of the company but even more than that, the media is one of the important stakeholders and a partner for the PT. Toyota Astra Motor Itself.
\end{abstract}

Keywords: Public Relations, Media, Toyota

\section{INTRODUCTION}

PT. Toyota Astra Motor is an example of a company that has a strong commitment to fostering good relations with the media as one of its external stakeholders. PT. Toyota Astra Motor shows that the media is not only a tool to create a positive image for the company. But more than that, PT. Toyota Astra Motor positions the media as partners. This can be seen from the various media relations activities carried out routinely as part of the efforts of PT. Toyota Astra Motor is creating and maintaining a harmonious relationship with the media as well as an effort to manage the positive image of PT. Toyota Astra Motor in the eyes of the public. Public relations or public relations itself is part of management activities carried out on an ongoing basis by organizations/institutions/companies to maintain the image and form positive opinions from the public and the public (public) so that the organization/institution/company can gain the trust and support of the company. community (public), both internal and external, but especially from the public outside the organization/institution/company. This is done through an open company, a good relationship between the two is impossible to achieve. This is because there is a conflict in the roles of Public Relations and journalists. Journalists or the press have a role to disseminate information as well as to influence public opinion and perform social control functions. While Public Relations has a role to make positive publications about a company. Given the contradiction in the roles 
and functions of PR and the press, it is not surprising that when the press wants or asks for confirmation regarding negative issues or information about the company, the PR of the company concerned tends to avoid or cover up the negative issue.

" Usually, both parties will insist on maintaining their respective principles or prejudice against the other party, because on the one hand, for example, journalists think that PR/PRO officials are willing to provide press statements and information that only benefit the name of the company, press release materials. contains publications, or has a promotional tone in the interest of maintaining its image (image corporate maintenance). On the other hand, the public relations side always has a bad prejudice against the role of journalists who create "problems", by hunting down sensational stories, which are seen only in negative terms and things that can damage the company's image and so on"1

With the conflict in the role of mass media and the company's Public Relations, understanding from both parties as an effort to maintain and manage good relations is very important. Companies that grow to become big are generally targeted by the press because they carry out behaviors that relate to the interests of many people. This is where media relations or press relations activity becomes an important factor for efforts to form a company's image.

"Press Relations is a special activity from the public relations to communicate the delivery of messages, or certain information about institutional, company/institutional activities, products, and other individual activities that need to be published in cooperation with the press or mass media". ${ }^{2}$

The main purpose of holding press relations is "to create knowledge and understanding, so clearly not merely to spread a message according to the wishes of the parent company or the client in order to get" an image or figure more beautiful than the original in the public eye. ${ }^{3}$

Building press relations (press or media relations) is a measure of the success of a PR function, namely to assess the effectiveness of a PR work in an institution or institution. This success can be seen from the extent to which publicity through press coverage can benefit the company's image in the eyes of the public as a result of good cooperation between PR and the media. ${ }^{4}$

\section{DISCUSSION}

Companies that run media relations programs are generally companies that need mass media to support in achieving company goals. In detail, the objectives of media

\footnotetext{
${ }^{1}$ Rosady Ruslan. Praktik dan Solusi Public Relations (Jakarta : Ghalia Indonesia, 1992), 160161.

${ }^{2}$ Rosady Ruslan. Manajemen Humas dan Manajemen Komunikasi : Konsep dan Aplikasi. Edisi 1. Cetakan 2 (Jakarta : RajaGrafindo Persada, 1999), 154-155.

${ }^{3}$ Frank Jefkins. Public Relations : Edisi Ke Lima (Jakarta : Erlangga, 2004), 114.

${ }^{4}$ Rosady Ruslan. Manajemen Humas dan Manajemen Komunikasi : Konsep dan Aplikasi. Edisi 1.

Cetakan 2 (Jakarta : RajaGrafindo Persada, 1999), 29.
} 
relations for the organization are: (1) To get the widest possible publicity regarding the activities and steps of an institution/organization that are good for the public interest, (2) To gain a place in media coverage (coverage, reports, reviews, fair headings, objective, and balanced (balance) regarding things that benefit the institution/organization, (3) To get feedback from the public regarding the efforts and activities of the institution/organization, (4) To complement data/information for the leadership of the institution/organization to make Appropriate assessment (assessment) of situations or problems that affect the success of the activities of the institution/company, and (5) Creating a stable and sustainable relationship based on mutual trust and respect. 5

Also, the purpose of media relations is not merely to provide information, but to create a positive image for an institution concerned. The better our media relations, the better the image of our institution or company. Likewise, many companies are hit by chaos precisely because they shut themselves off from the press which results in a bad image that is forever entrenched in the minds of the public. ${ }^{6}$ By having good relations with the media, all organizational activities will benefit, or at least be assisted in their efforts to protect the good image of the organization or company. ${ }^{7}$

"By far the most critical component in media relations is developing and maintaining a network of contact with media. Building and maintaining close relationships is a prerequisite for generating coverage. A company cannot simply turn the relationship on and off when a crisis strikes or when it has something it would like to communicate to the public. Instead, firms need to work to develop long-term relationships with the right journalist for their specific industry. This effort usually means meeting with reporters just to build goodwill and credibility. The media relations director should meet regularly with a journalist who covers the industry and also should arrange yearly meetings between key reporters and the CEO. The more private and privileged these session are, the better the long-term relationship is likely to be".8

Fostering press relations is not only necessary for a company when faced with a crisis. Therefore, fostering good relations with the media is an important thing that must be considered and carried out by a company at all times. In maintaining good relations with the media, several things must be considered by a company.

\footnotetext{
${ }^{5}$ Diah Wardhani. Media Relations : Sarana Membangun Reputasi Organisasi (Yogyakarta: Graha Ilmu, 2008), 13.

${ }^{6}$ Nurudin. Hubungan Media : Konsep dan Aplikasi (Jakarta : Raja Grafindo Persada, 2008), 13.

${ }^{7}$ John P. Simandjuntak dkk. Public Relations (Yogyakarta : Graha Ilmu, 2003), 149.

${ }^{8}$ Paul A. Argenti. Corporate Communication (New York: The McGraw-Hill Companies, 2009), 165.
} 
Things that need to be considered in carrying out media relations activities are understanding the media as a whole which includes: (1) Understanding the characteristics of each media, (2) Understanding the public (social, economic, educational, cultural values) of each media, (3) Understanding of how journalists work in each media, (4) Understanding of the country's political system, (5) Understanding of the prevailing media system, and (6) Understanding of the legal system, laws, and regulations. ${ }^{9}$

"There are three interests from three different parties served by the media relations officer. However, from the three different interests, the fulfillment of the interests and needs of the mass media will be able to fulfill the interests of the other two parties, namely the organization and the public. Herein lies the strategic role of the media relations officer in establishing harmonious communication between the organization and the public. ${ }^{10}$

With the importance of the role of the mass media, it is not appropriate to consider the mass media as a tool. For a company, the mass media are partners. By positioning the mass media as an image, the position of public relations officer or media relations officer and media personnel are equal. Neither party has a higher position, because both of them need each other. The media relations officer needs the media so that the organization can communicate with its publics. Media people also need a media relations officer as a source of news-worthy information to be conveyed to the media audience (Iriantara, 2005: 18).

In maintaining good relations with the media, several tips need to be done by a Public Relations Officer (PRO), including (a) Servicing Media, successful public relations practitioners are those who can establish good relations with the media because almost five activities are carried out. Thirty percent are related to the media. This relationship does not mean that the media are the ones that need company data, but that it is companies that need media publicity. So, to create good relationships, understand and serve the needs of the media to be the main,11 (b) Establishing a Reputations for Reliability, Honesty, and credibility, so that journalists will have full confidence in PRO. Also, PR practitioners can provide information to give journalists ideas for developing their stories. ${ }^{12}$ This method will not only bring closer relations with journalists but also build a good reputation. Public relations practitioners will be trusted as sources of reliable, complete, and accurate information about their company, (c) Supplying Good Copy, Providing services for other information or data (photos, images, etc.) quickly, most definitely, with the most accurate data. true

\footnotetext{
${ }_{9}^{9}$ Diah Wardhani. Media Relations : Sarana Membangun Reputasi Organisasi (Yogyakarta: Graha Ilmu, 2008), 15.

${ }^{10}$ Yosal Iriantara. Media Relations : Konsep, Pendekatan, dan Praktik (Bandung: Remaja Rosdakarya, 2005), 18.

${ }^{11}$ Nurudin. Hubungan Media : Konsep dan Aplikasi (Jakarta : Raja Grafindo Persada, 2008), 47.

${ }^{12}$ Diah Wardhani. Media Relations : Sarana Membangun Reputasi Organisasi (Yogyakarta:

Graha Ilmu, 2008), 15.
} 
anytime without time and place limit,13 (d) Cooperation in Providing Material, because the work of public relations practitioners is closely related to journalists, the two parties must work together well. For example, cooperation to prepare and conduct interviews or press meetings with certain figures, ${ }^{14}$ (e) Providing Verification Facilities, If the reporters still have doubts about the material provided by the PR practitioner, the PR practitioner must be ready to accept reporters who want to re-check the material, ${ }^{15}$ and (f) Building Personal Relationship with The Media, Honesty, openness, and mutual understanding between PR and journalists should be done. Only in this way will a strong relationship be properly nurtured. A good relationship will certainly have implications for good news as well. However, with bad personal relationships, even good news can be bad.

In its implementation, media relations activities can be realized in various activities, including (1) Press Conference, namely a meeting or special contact with the press that is official or deliberately held by a public relations official, who acts as a resource to explain a plan or Certain problems he is currently facing are in the form of a press conference where the time, place, theme of the press conference has been determined with a group of journalists who each represent various mass media who are registered as participants and officially invited,16 (2) Press Tour, is an event organized by an organization to give journalists the opportunity to know the conditions, activities, and problems that the organization may face. Through this activity, companies can save costs because the company no longer carries out promotions or other activities that require money. Another advantage of this activity is that journalists will feel that they are considered part of their own family by the company so that journalists will have an emotional connection internally. The expected impact is of course for the media to cover only the good things of the company, (3) Press Reception and Press Gathering, press meetings of this kind, namely social press/journalist banquets, attending receptions, or certain ceremonies. formal or informal. ${ }^{17}$ In this event, journalists were invited to cover an event organized by the company. There is also use of gathering through joint sports events, gathering together at company birthdays, at religious events such as breaking the fast, New Years and Christmas together between public relations and executives with the press at an event outside their respective functional duties. . The purpose of this event is to get closer to the company and the press, (4) Press Visit (Facility Visit). Often a company invites journalists to visit its company. For example, a new product is being launched or a new factory is being built in a location. Journalists are often allowed to enter each side of the room where they want to be

\footnotetext{
${ }^{13}$ Ibid.

${ }^{14}$ Nurudin. Hubungan Media : Konsep dan Aplikasi (Jakarta : Raja Grafindo Persada, 2008), 48.

${ }^{15}$ Ibid.

${ }^{16}$ Rosady Ruslan. Praktik dan Solusi Public Relations (Jakarta : Ghalia Indonesia, 1999), 194.

${ }^{17}$ Ibid., 179.
} 
shown, and (5) Press Release, is information in the form of news made by the Public Relations (PR) of an organization/company, which is submitted to the press manager/media editor. mass (TV, radio, newspapers, magazines) to be published in the mass media. The information conveyed is general information related to organizational developments, special events or incidents, management/policy changes, or other matters that have high news value. The delivery of this press release generally not only utilizes the mass media but also utilizes the website owned by the company concerned.

"The purpose of making this press release cannot be separated from the objectives of PR in general and the organization as a whole. But specifically, press releases also aim to convey information to the public which is geographically dispersed, thus using the mass media to convey it. The appearance of information from that organization in the mass media has another positive impact. Internally, the frequent information from that organization appears in the media will increase the sense of pride in the employees working in the organization. Externally, the emergence of news about the organization will contribute to increasing the positive image and reputation of the organization. Of course, if the news broadcast by the media is indeed news that is viewed positively by the organization". 18

\section{CASE STUDY}

PT. Toyota Astra Motor (TAM) is the sole agent for the Toyota car brand in Indonesia. PT. Toyota Astra Motor was inaugurated on April 12, 1971. The role of PT. Toyota Astra Motor was originally only an importer of Toyota vehicles. However, a year later this company acted as a distributor. On December 31, 1989, PT. Toyota Astra Motor has merged with three companies, namely PT. Multi Astra, PT. Toyota Mobilindo, and PT. Toyota Engine Indonesia. The association of these companies was then given the name PT. Toyota Astra Motor. ${ }^{19}$

As a company engaged in the automotive business, PT. Toyota Astra Motor seems to be fully aware of the role of the media as one of its external stakeholders. Moreover, the automotive business cannot be separated from various issues that have the potential to damage the image of the company, one of which is the issue of a product recall or recall in recent years. Therefore, a good relationship with the media will really help PT. Toyota Astra Motor is managing its image.

In an effort to create and maintain good relations with the media, PT. Toyota Astra Motor Indonesia carries out various activities, including (a) Media Gathering event, an activity held regularly by PT. Toyota Astra Motor as an effort to get closer to the media crew. This was disclosed by the Marketing Director of PT. Toyota Astra Motor, Joko Trisayonto, "I would like to thank you for the cooperation with all media colleagues. I hope that with this media gathering we, namely Toyota and the mass

\footnotetext{
${ }^{18}$ Yosal Iriantara. Media Relations : Konsep, Pendekatan, dan Praktik (Bandung: Remaja Rosdakarya, 2005), 199.

${ }^{19}$ www.subscribd.com/doc/20685966/Toyota-Astra-Motor
} 
media, will become a more solid team in the coming years". ${ }^{20}$ This Toyota Media Gathering event is held twice a year, with the headings "Early Year Media Gathering" and "End Year Media Gathering".

The Media Gathering event held by Toyota is not only used as a gathering place for PT. Toyota Astra Motor with a media crew, but also filled with various other activities, such as games, test drive Toyota cars, and giving gifts to media crews. This event is also used by Toyota to deliver the latest information about the company and its products. One example is the Toyota Early Year Media Gathering 2011 event which was not only used to gather with the press, but was also used by Toyota to convey information about the impact of the Japanese earthquake and tsunami disaster on Toyota car production. ${ }^{21}$ (b) Press Conference, efforts to foster good relations with the media, were also carried out by PT. Toyota Astra Motor by holding a press conference. In this case, the press conference was not only conducted by PT. Toyota Astra Motor is related to product-related issues but is also carried out to inform Toyota's new products, the achievement of sales of Toyota products, to activities carried out by PT. Toyota Astra Motor, (c) Press Visit, in connection with the press visit activity to the Toyota factory, PT. Toyota Astra Motor created a program entitled "Plant Visit". Plant Visit is part of the Education-Industry cooperation program launched by PT. Toyota Motor Manufacturing Indonesia. More specifically, Plant Visit is a program in the form of reviewing production facilities and supporting facilities..$^{22}$ Through this program, the community and the media are allowed to visit Toyota factories. The media, which is known for its trusted information institutions, is still unable to provide the required information. By holding this program, it is hoped that the media can inform Toyota's concern for community development and environmental care, (d) Press Tour, about the Press Tour activities, PT. Toyota Astra Motor has invited the media crew several times to tour to provide information about various matters related to the company to the media crew. One of them is the Press Tour which was held in 2010 where PT Toyota Astra Motor (TAM) invited dozens of Indonesian journalists from various media to Japan. This week's trip (18-23 / 10) followed many activities that were packaged by ATPM Toyota Indonesia. Among them witnessed the opening of the 2009 Tokyo Motor Show automotive exhibition. Not only that, journalists were invited to the Tsutsumi Plant, a factory for the Toyota Prius hybrid sedan that has sold 1.26 million units (from 1997 to 2008) to see first-hand the production process. ${ }^{23}$ and (e) Press Release, not only trying to get closer to the media, PT. Toyota Astra Motor also

\footnotetext{
${ }^{20}$ www.inilah.com/read/detail/68556/toyota-gelar-end-year-media-gathering

${ }^{21}$ www.oto.detik.com/read/2011/05/11/184410/1637623/648/toyota-bulan-juni-produksi-mobiltoyota-di-asia-pulih

${ }^{22}$ www.toyota.astra.co.id/csr/ecosafety/others/article.php?article id=2008 23
}

www.otomotif.kompas.com/read/xml/2009/10/19/2217405/Melihat.Proses.Perakitan.Toyota.Prius.di. 
strives to provide space for media crews to obtain various information about company activities through press releases published on the website www.toyota.astra.co.id as well as in various types of mass media. Apart from press releases, on the site PT. Toyota Astra Motor also provides a "Toyota in the News" feature which provides various information about Toyota products. Plus, PT. Toyota Astra Motor also provides data in the form of photos and TVC for the events being held, all of which can be accessed by the media crew at any time.

From the description of Media Relations activities mentioned above, PT. Toyota Astra Motor has shown its commitment to establish and manage good relations with the media, as a working partner at all times, not just in times of crisis. For example, Media Gathering activities. The Toyota Media Gathering event which is held twice each year is a form of gratitude for PT. Toyota Astra Motor to the media crew for the cooperation that has been established. The implementation of this event is an excellent Media Relations strategy because through this event the media crew feels more valued. In addition, through this event, PT. Toyota Astra Motor can get closer to the media crew. This is quite important, considering the closeness between PT. Toyota Astra Motor with the media crew is part of the efforts of PT. Toyota Astra Motor in building good relations with the media is one of the important tips in implementing Media Relations activities. Then, for press conference activities conducted by PT. Toyota Astra Motor itself, this activity is a pretty good step. This is because of PT. Toyota Astra Motor often holds press conferences related to various things, from informing Toyota's new products, Toyota product sales achievements, to activities carried out by PT. Toyota Astra Motor, and not only do it when there are issues or crises in the company, such as during the earthquake and tsunami in Japan some time ago.

“Journalists generally need news. Every day he looks for news. Not a few of them who work in a month (for daily newspapers) have to collect at least 20 stories. This doesn't mean they weren't looking for news after that. They are still looking for reasons both to get a bonus from their company and to seek credibility for advancing their professional level". ${ }^{24}$ (Nurudin, $2008: 59$ ).

PT. Toyota Astra Motor seems to understand that journalists need news. Therefore, PT. Toyota Astra Motor often invites journalists to attend press conferences which it holds to provide various important information related to the company. Through this press conference, PT. Toyota Astra Motor also shows its commitment to serving the media (servicing media) which is one of the principles of Media Relations activities.

In addition, the press visit and press tour activities were held by PT. Toyota Astra Motor is another manifestation of PT. Toyota Astra Motor is maintaining good relations with the media crew at all times. Steps were taken by PT. Toyota Astra Motor is quite good because generally, the company will only invite journalists when they need it.

${ }^{24}$ Nurudin. Hubungan Media : Konsep dan Aplikasi (Jakarta : Raja Grafindo Persada, 2008), 59. 
"From now on, invite them when you don't even need publication. For journalists, such activities will be considered that the company not only needs him when there is news but also wants to build good relations with journalists, whether there is an event or not because the impression that companies only want to invite journalists when they are needed is still firmly planted in the mind management of the company today, even in the minds of journalists". ${ }^{25}$

By holding a press visit and press tour, PT. Toyota Astra Motor shows that they do not see the media as merely a tool for image formation. This can be seen from how PT. Toyota Astra Motor also invited journalists even when they didn't need publication. PT. Toyota Astra Motor opens the widest possible space for the media to get information about Toyota companies and products. In addition, the press visit and press tour activities were conducted by PT. Toyota Astra Motor shows that PT. Toyota Astra Motor opens the widest possible space for the media to get information about Toyota companies and products. This is quite important in educating or informing journalists about various matters related to company performance. Furthermore, the latest Media Relations activities were carried out by PT. Toyota Astra Motor is through a press release. For this press release activity, PT. Toyota Astra Motor utilizes various types of mass media, such as television, newspapers, and online media to publish various news related to the company and its products. Not only that, PT. Toyota Astra Motor also maximizes the function of the www.toyota.astra.co.id website as a medium for publishing its press releases. Data such as articles about Toyota, videos, and event photos are provided in the Toyota News feature, Photo collection, and TVC events which are published and can be accessed anytime on the www.toyota.astra.co.id site.

Press release content provided by PT. Toyota Astra Motor in the Media Relations feature on the www.toyota.astra.co.id website is quite interesting. Provision of press release content published on the website www.toyota.astra.co.id which includes articles, photos, and videos related to all matters related to PT. Toyota Astra Motor later became the hallmark of the Media Relations activities of PT. Toyota Astra Motor. This is because most companies, both those engaged in the automotive sector and those engaged in other fields, generally only provide press release content in the form of articles related to the company. One example is PT. Honda Prospect Motor. On the website www.honda-indonesia.com, PT. Honda Prospect Motor only provides articles related to the product and company. Likewise with PT. Mazda Motor Indonesia. On its website, namely www.mazda.co.id, Mazda only provides articles as press release content which are presented in a feature entitled "Mazda News". The completeness of the press release content provided on the website www.toyota.astra.co.id is what characterizes and differentiates PT. Toyota Astra Motor with other companies. 
Provision of a fairly complete press release content on the website www.toyota.astra.co.id is certainly very influential on the Public Relations activities of PT. Toyota Astra Motor in fostering good relations with the media as well as in forming a positive image of the company.

"News releases create a certain image in the critical eyes of the editors regarding the organization that disseminates them. However, the reality is that this news broadcast is still one of the PR activities that is not taken seriously. This fact is very unfortunate considering the real importance of the news broadcast so great. Editors from various mass media are often disappointed to see the low quality of news broadcasts they receive from the PR circle. Of course, this can damage press relations which in the end will harm the organization or company concerned ".26

The provision of sufficiently complete press release content is one of the most important factors in implementing Media Relations activities. This is because the provision of sufficiently complete press release content reflects the seriousness and commitment of PT. Toyota Astra Motor is meeting the needs of the media crew. Also, the provision of complete press release content on the www.toyota.astra.co.id website also greatly helps the performance of the Public Relations Officer (PRO) of PT. Toyota Astra Motor. This means that the Public Relations Officer of PT. Toyota Astra Motor has other alternatives to publish news related to the company and its products, not only relying on and depending on the coverage made by media crews and press releases that are intentionally sent to various mass media. This is of course very profitable. PRO PT. Toyota Astra Motor, because by providing complete press release content on the website www.toyota.astra.co.id, PRO PT. Toyota Astra Motor can save costs used for Media Relations activities, especially those related to publication through press releases.

And last but not least, the provision of sufficiently complete press release content also shows Toyota's efforts in implementing the Suppliying Good Copy tips for media crews as one of Toyota's commitments in building good relations with the media itself. This is quite important, considering that with the provision of sufficiently complete and high-quality press release content, media crews certainly feel more valued by its existence.

Overall, PT. Toyota Astra Motor as an international automotive company has been able to demonstrate its commitment to building good relations with the media. This can be seen from the seriousness of PT. Toyota Astra Motor maintains good relations with the media at all times, not only at certain times, especially when the company is experiencing a crisis through media gathering activities, press conferences, press visits, press tours, and press releases. Not only that, PT. Toyota Astra Motor has also shown how they position media crews as partners, not just as tools. Therefore, it is no exaggeration of the media relations activities of PT. Toyota

${ }^{26}$ Frank Jefkins. Public Relations : Edisi Ke Lima (Jakarta : Erlangga, 2004), 121. 
Astra Motor has come to be cited as an example of the ideal implementation of media relations activities.

\section{CONCLUSION}

PT. Toyota Astra Motor is an example of a company that has a strong commitment to fostering good relations with the media as one of its external stakeholders. PT. Toyota Astra Motor shows that the media is not only a tool to create a positive image for the company. But more than that, PT. Toyota Astra Motor positions the media as partners. This can be seen from the various media relations activities carried out routinely as part of the efforts of PT. Toyota Astra Motor is creating and maintaining a harmonious relationship with the media as well as an effort to manage the positive image of PT. Toyota Astra Motor in the eyes of the public.

\section{REFERENCES}

Abdullah, Aceng. Press Relations : Kiat Berhubungan Dengan Media Massa. Bandung: Remaja Rosdakarya, 2004.

Ardianto, Elvinaro. Public Relations Praktis: Pendekatan Praktis untuk Menjadi Komunikator, Orator, Presenter, dan Juru Kampanye Handal. Bandung: Widya Padjajaran, 2009.

Argenti, Paul A. Corporate Communication. New York: The McGraw-Hill Companies, 2009.

Cutlip, M. Scott, Allen H. Center, \& Glen M. Broom. Effective Public Relations, 8th Edition. Amerika: Prentice Hall, 2000.

Harvard Bussiness School. The Essentials of Corporate Communications and Public Relations. Massachusett : Harvard Bussiness School Press, 1992.

Iriantara, Yosal. Media Relations : Konsep, Pendekatan, dan Praktik. Bandung: Remaja Rosdakarya, 2005.

Jefkins, Frank. Public Relations : Edisi Ke Lima. Jakarta: Erlangga, 2004.

Kasali, Rhenald. Manajemen Public Relations : Konsep dan Aplikasinya di Indonesia. Jakarta : Pustaka Utama Grafiti, 2003.

Nurudin. Hubungan Media : Konsep dan Aplikasi. Jakarta : Raja Grafindo Persada, 2008.

Rudy, Teuku May. Komunikasi \& Hubungan Masyarakat Internasional. Bandung: PT. Refika Aditama, 2005.

Ruslan, Rosady. Praktik dan Solusi Public Relations. Jakarta : Ghalia Indonesia, 1999. . Manajemen Humas dan Manajemen Komunikasi : Konsep dan Aplikasi.

Edisi 1. Cetakan 2. Jakarta: Raja Grafindo Persada, 1999.

Simandjuntak, John P. dkk. Public Relations. Yogyakarta : Graha Ilmu, 2003.

Wardhani, Diah. Media Relations : Sarana Membangun Reputasi Organisasi. Yogyakarta: Graha Ilmu, 2008.

Sirait, Agusta B. Toyota Gelar End Year Media Gathering. www.inilah.com/read/detail/68556/toyota-gelar-end-year-media-gathering Akses 15-05-2011, 2008. 
Sribd Inc. Toyota Astra Motor. www.subscribd.com/doc/20685966/Toyota-Astra-

Motor Akses 1-5-2011, 2011.

Iksan, Muhammad. Toyota: Bulan Juni Produksi Mobil Toyota di Asia Pulih.

www.oto.detik.com/read/2011/05/11/184410/1637623/648/toyota-bulan-juniproduksi-mobil-toyota-di-asia-pulih, Akses 15-05-2011.

Bastian. 2009. Melihat Proses Perakitan Toyota Prius di Tsutsumi. www.otomotif.kompas.com/read/xml/2009/10/19/2217405/Melihat.Proses .Perakitan.Toyota.Prius.di.Tsutsumi, Akses 15-05-2011.

www.toyota.astra.co.id/csr/ecosafety/others/article.php?article_id=2008，Akses 15-05-2011. 